\title{
Constructional Design of Bamboo Slanted Ceiling for Lower Material Surface's Temperature and Humidity Levels
}

\author{
Nabila Afif', Eugenius Pradipto' ${ }^{1}$, Maria Ariadne Dewi Wulansari1 ${ }^{1}$, Riri Chairiyah² \\ ${ }^{1}$ Lecturer, Department of Architecture and Urban Planning, Faculty of Engineering, Universitas Gadjah Mada \\ ${ }^{2}$ Lecturer, Department of Architecture, Faculty of Sains and Technology, Aisyiyah University \\ nabilaafif@ugm.ac.id
}

\begin{abstract}
In Indonesia, a bamboo slanted ceiling is one of the most commonly used types of ceiling. It occurs for numerous reasons, including technical and cultural aspects. However, practically, it has low durability and is difficult to maintain as it is used in place which is prone to rainwater seepage and installed in the form of large woven sheet material. Therefore, in this research, three alternative models of construction for a bamboo slanted ceiling were proposed: (1) one layer of dense bamboo slats, (2) two layers of dense bamboo slats; and (3) two overlapping layers of sparsely weaved bamboo slats. Each model was developed on a real scale prototype and tested in terms of its material's temperature and humidity level. The construction strategies used for these models were focused on the arrangement and orientation of pieces of 'Bambu Kuning' within the roof structure. The measurement result shows that the third model had the lowest temperature with $>5^{\circ} \mathrm{C}$ different compared to the other models during the hottest hour of the day (from 9 AM to $3 \mathrm{PM}$ ). Then, in terms of the humidity measurement, data shows that the second model had the lowest humidity measurement with $1.93 \%$ different compared to the first model and $1.22 \%$ different compared to the third model. Furthermore, other potential benefits of the proposed models are also presented.
\end{abstract}

Keywords: slanted ceiling, bamboo ceiling, constructional design, green building material

\section{Introduction}

\subsection{Slanted ceiling from a technical and cultural perspective}

A slanted ceiling is one of the most common types of ceiling found in a conventional type of housing, especially in one-story housing where most of the room areas have a direct connection with the roof structure. From a design perspective, the use of a slanted ceiling is an effective way to create a spacious room as the ceiling follows the overall shape of the roof. Thus, it leaves a maximum space beneath the ceiling. Then, from a building performance point of view, the aforementioned aspect of a slanted ceiling is often associated with the environmental performance of the room in correspondence to the local climates of the site; in this case, places with a hot and humid climate. As hot air rises, the greater the distance between the floor surface and the ceiling surface, the cooler the air going to be in the lower part of the room where most of the activities often take place. Such utilization of a high slanted ceiling has been reflected in various designs of traditional houses in tropical countries such as Indonesia, Philippines, and Brazil among many more countries, as seen in Table 1. 
Table 1. Designs of traditional houses with slanted ceiling

\begin{tabular}{lccccc}
\hline Country list & House name & Exterior view & Interior view \\
Indonesia & Limasan House & (Image source: rumahjoglo.net, 2015) & (Image source: rumahjoglo.net, 2015) \\
Philippines & Ifugao House & (Image source: Wimmer, 2013) & (Image source: Wimmer, 2013) \\
Brazil & Oca House & (Image source: Casas na Terra, 2017) & (Image source: Casas na Terra, 2017) \\
\hline (Source: Author's analysis, 2019) & &
\end{tabular}

In Indonesia, a slanted ceiling is popular for numerous reasons. In addition to its technical advantages, given the local context of Indonesia, a slanted ceiling also has a stronger association with the theory of microcosm and macrocosm in comparison to a flat ceiling. Researches have shown that the theory has been adapted massively in Indonesian local beliefs, where some have referred to as "Manunggaling Kawula Gusti" (Mangunwijaya, 2009; Triyuwono, 2011; Umar, Faslih, \& Rosyidah, 2018). Despite its many slightly varied interpretation, the theory revolves in defining the relationship between the common creatures (such as humans) and the higher power (the creator or God; or the King) (Australia Plus ABC, 2016; Mangunwijaya, 2009). Concerning the slanted ceiling, the shape of such building element is considered reflecting the values of a united, strong relationship between the two entities by allowing a direct and borderless connection between the lower part of the space (which represent the common creature) and the upper part of the space (which represent the higher power) within the enclosed room. Research also showed that to some extent, this connection is even extended to the other part of the building, such as the tip of the slanted roof structure which is considered as the highest point of the building (called "Nok" in traditional Javanese house). This building element is seen as the departure point which forwards the higher power and the common creature's connection that is further beyond the boundary of the building. Illustrations on the translation of this concept excerpted from other research are presented in Table 2 .

Table 2. Translation on the concept of microcosmic and macrocosmic

\begin{tabular}{ll}
\multicolumn{1}{c}{$\begin{array}{c}\text { Research } \\
\text { Source }\end{array}$} & \multicolumn{1}{c}{ Conceptual framework } \\
\hline $\begin{array}{l}\text { (Ambarwati, } \\
2009)\end{array}$ & $\begin{array}{l}\text { Javanese house is the axis of the world and the } \\
\text { image of the world. It is a place of unification of the } \\
\text { microcosm (Javanese people) with the macrocosm } \\
\text { (the universe and the magical powers) that } \\
\text { dominate it. }\end{array}$ \\
(Image source: Ambarwati, n.d.)
\end{tabular}


(Mangunwijaya, The architectural layout of Pendopo illustrates the 2009)

(Adiyanto, 2012)

balance of the human relationship with God (vertical relationship through a vertical orientation of building layout) and the human relationship with other humans (horizontal relationship through a horizontal orientation of building layout).

The roof of the building is the most sacred place, while the space under the building (in the context of the stilt house) becomes the dirtiest place. This concept is a transformation from the theory of sacrality in space in Javanese house.

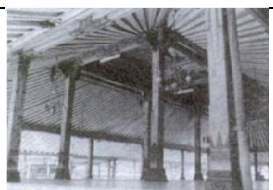

(Image source: Mangunwijaya, 2009)

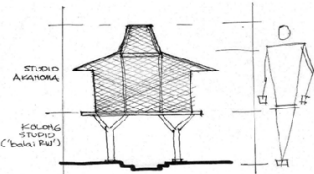

(Image source: Adiyanto, 2012)

(Source: Author's analysis, 2019)

\subsection{Bamboo as natural material for ceiling material}

In terms of material, there is a large range of materials that could be used for ceiling material. Among the common options, a bamboo ceiling is often considered as one of the most sustainable choices in Indonesia. In general, bamboo is fast-growing and relatively inexpensive as it is easily available in the area. Then, from a constructional point of view, bamboo is very light in weight and is very flexible. Thus, it is ideal to be used as a ceiling in earthquake-prone areas such as in Indonesia. Even when the ceiling is falling, it has a lower chance of hurting people underneath in comparison to other-modern ceiling material (Raj \& Agarwal, 2014). The use of a bamboo ceiling in various designs is shown in Figure 1.

Furthermore, it also shares the same material properties of hygroscopic with other porous material such as timber. Research has shown that such types of material are possessing a moisture buffering phenomenon, which is the ability to absorb and release moisture depending on the relative humidity of the room. Although the accurate calculation on its implication is not yet accommodated by current Building Energy Simulation programs (BES), the added values in terms of improving the climatic performance of the room by utilizing such material in its interior have clearly indicated already (Steeman, Janssens, Steeman, Van Belleghem, \& De Paepe, 2010).

Nevertheless, it is widely known a bamboo is prone to damage when used in contact with water, whereas the ceiling is located right under the roof structure which is highly at risk of rain seepage that could penetrate through gaps between the tiles. Commonly, under the circumstances that the bamboo ceiling is damaged, such a problem is solved by replacing the damaged bamboo ceiling with the new one. However, although the solution seems fine in theory, it could become a tedious work in practice regardless of the type of construction. The material used for a bamboo ceiling is often sold in the form of flat, thin sheets cut in a large dimension called 'gedheg' or woven bamboo sheet, as shown in Figure 2. Thus, partial replacement of one particular section of the ceiling is not a highly viable action and is often delayed for such technical issues.

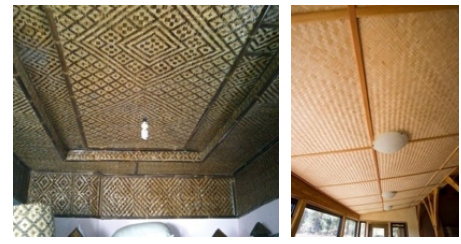

Figure 1. Bamboo ceilings in various pattern (Image source: https://cutt.ly/8whe4jP, https://cutt.ly/kwhe7bY, August 27, 2019)

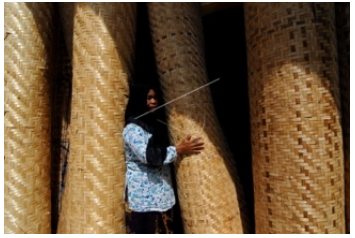

Figure 2. Bamboo sheets sold in large dimension (Image source: https://cutt.ly/Dwhe71f, August 27, 2019) 


\subsection{Constructional variations of a slanted ceiling}

Reviewed from the way the ceiling is fitted into the roof's structure, a slanted ceiling could be classified into two groups, such as (1) slanted ceiling fitted below the common rafter, and (2) slanted ceiling fitted between the common rafter and the tile battens. In general, slanted ceiling models belong to the first group that displays a more spacious impression as the materials are stretched widely and continuously throughout the room area, as seen in Figure 3. On the other hand, ceiling models belong to the second group gives the impression of a more compartmentalized room because of the visible elements of the common rafter under the ceiling material, as seen in Figure 4.

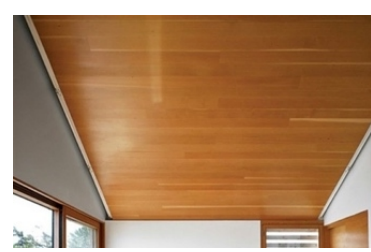

Figure 3. Slanted ceiling fitted below the common rafter (Image source: https://cutt.ly/wwhe5Zo, August 25, 2019)

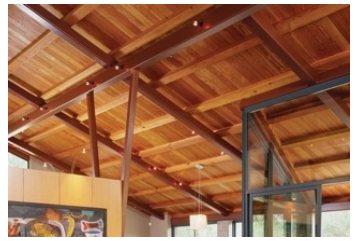

Figure 4. Slanted ceiling fitted in between the common rafter and the tile battens (Image source: https://cutt.ly/9whe59o, August 25, 2019)

Overall, the main difference between the two types of slanted ceiling lies in the width of the resulted space between two elements of the roof structure; specifically, the space between the inner surface of the tiles and the outer surface of the ceiling, as seen in Figure 5. More detailed implications of this different spatial dimension are presented as a list of advantages and disadvantages in Table 3.

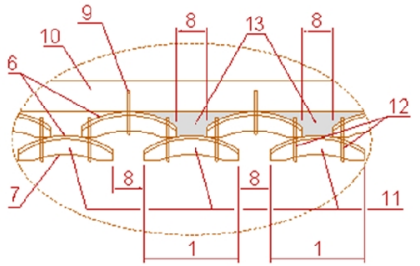

Figure 5. Illustration of space in between the roof structure and the ceiling (shaded in light grey color) (Image source: Pradipto, 2019)

Table 3. Spatial implication on different types of construction for slanted ceiling

\begin{tabular}{|c|c|c|c|}
\hline $\begin{array}{c}\text { Types of slanted ceiling } \\
\text { construction }\end{array}$ & $\begin{array}{c}\text { Spatial } \\
\text { characteristic result }\end{array}$ & Advantage & Disadvantage \\
\hline $\begin{array}{l}\text { Slanted ceiling fitted below } \\
\text { the common rafter }\end{array}$ & $\begin{array}{l}\text { A larger gap between the } \\
\text { roof structure and the } \\
\text { ceiling }\end{array}$ & $\begin{array}{l}\text { Better thermal protection } \\
\text { from outdoor } \\
\text { temperature } \\
\text { More accessible for } \\
\text { maintenance }\end{array}$ & $\begin{array}{l}\text { Large space provides more space for } \\
\text { domestic pests such as rats, bats, } \\
\text { squirrels, cockroaches, etc. } \\
\text { - }\end{array}$ \\
\hline $\begin{array}{l}\text { Slanted ceiling fitted in } \\
\text { between the common rafter } \\
\text { and the tile battens }\end{array}$ & $\begin{array}{l}\text { A smaller gap between the } \\
\text { roof structure and the } \\
\text { ceiling }\end{array}$ & $\begin{array}{l}\text { Small space eliminates } \\
\text { the potential for pests' } \\
\text { inhabitance } \\
\text { - }\end{array}$ & $\begin{array}{l}\text { Relatively small air insulation (2-3 } \\
\mathrm{cm} \text { ) leads to rapid outdoor heat } \\
\text { transfer } \\
\text { Limited access for maintenance }\end{array}$ \\
\hline
\end{tabular}

(Source: Author's analysis, 2019)

\subsection{Research objective}

Therefore, this research was aimed to investigate the impact and effectiveness of three design-based construction techniques of a bamboo ceiling which were proposed as 
alternative solutions to overcome the disadvantages of the second type of construction of the slanted ceiling (in reference to Table 1). These construction techniques were developed as a result of natural material exploration from the perspective of architectural engineering. The three construction techniques were all based on a similar principle of a modular product on natural material with minimum effort on both of the material treatment itself and on the construction tool to push further the concept of sustainable architecture through simple building material technology. In this research, 'Bambu Kuning' (Bambusa vulgaris var. striata) was chosen as the single natural material, and the term 'effectiveness' was defined limited only to the ability of the construction to reduce the temperature and humidity level on the surface of the building material itself. In this context, a reduced temperature and humidity level on the material' surface was established as a basic indication of good climatic performance and high durability of the material.

\section{Material and method}

In this research, the focus lies on the exploration of three types of a modular slanted bamboo ceiling made of raw and untreated bamboo logs of Bambu Kuning. This type of bamboo was chosen as it is among one of the most commonly found types of bamboo in the region. Although generally it is varied in size, the type of bamboo used in this research measured 6-8 cm in its overall outer diameter with around $2 \mathrm{~cm}$ in thickness. During the research, a parametric design tool of Rhinoceros with Grasshopper plugin was used. However, it is important to note that the use of this software was only to input numeric data necessary effectively for the parameter-based simulation which was crucial to provide controllable and precise visual information of the construction process for each type of module. The detailed method of construction for each modular bamboo ceiling including their underlying design logic and detailed method of data collection used for the data analysis in this paper are explained in the two following subsections.

\subsection{Method of construction}

As previously mentioned, there are three different types of modular slanted bamboo ceiling used in this paper, namely (1) one independent layer of dense bamboo slats; (2) two stacked layers of dense bamboo slats; and (3) two overlapping layers of sparsely weaved bamboo slats. Each of the modules was developed in a 1:1 scale prototype of the modular bamboo ceiling with differences between each type of module lies in the way the bamboo slats were arranged as a unit of slanted bamboo ceiling module. The digital modeling of each type of module is presented in Table 4.

Table 4. Graphical data on each type of ceiling model

$\begin{gathered}\text { Type } \\ \text { name }\end{gathered}$
Modular section


Module 2
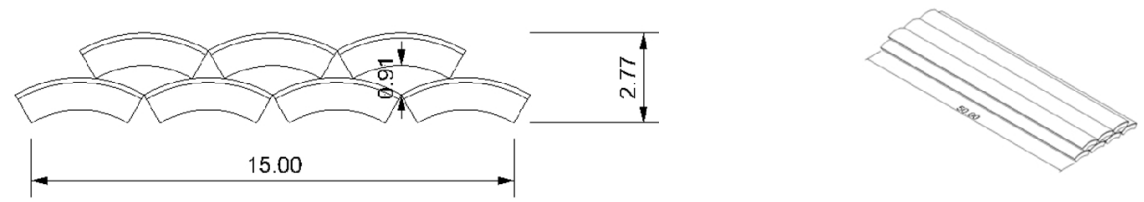

Module 3
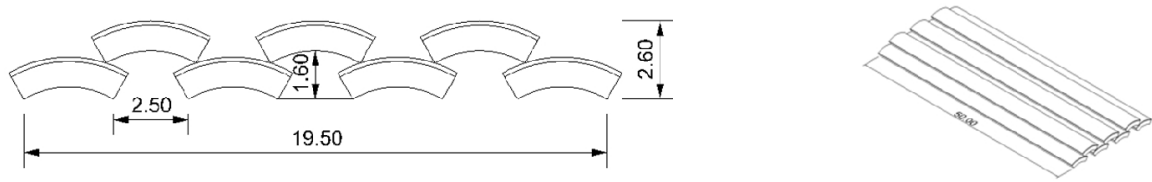

(Source: Author's analysis, 2019)

The bamboo slats were obtained by splitting the log of Bambu Kuning into pieces with approximately $50 \mathrm{~cm}$ in length is perpendicular to the direction of the bamboo fibers. This size was chosen as it was designed to cover more than twice the length $(l=2 n+5)$ of the conventional type of clay tiles used in the house where the measurement took place, as seen in Figure 6. Then, the shorter bamboo logs were split into six equally in the direction of the bamboo fibers, illustrated in Figure 7.

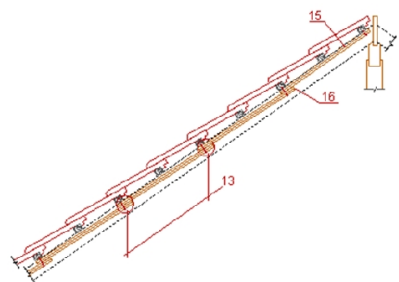

Figure 6. Length of the module is twice the distance between tiles

(Image source: Pradipto, 2019)

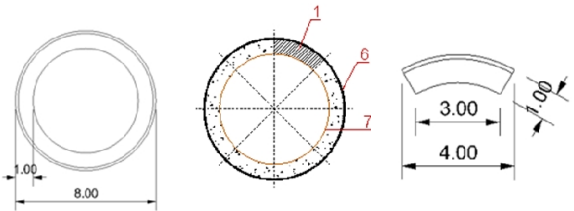

Figure 7. Splitting process of the bamboo (Image source: Pradipto, 2019)

These bamboo slats were then put together as a custom-sized modular material to be fitted in between the common rafter and the tile battens. In this research, the dimension of the module used was approximately $50 \times 50 \mathrm{~cm}$, and the number of bamboo pieces used by each module of each construction type is presented in Table 5 . Technically, all the types of modules were placed side by side as the slanted ceiling with each type of modules was covering around $0,5 \mathrm{~m}^{2}$ of ceiling area $(0,5 \mathrm{~m} \times 1 \mathrm{~m})$ underneath a wooden tilted roof structure covered by clay roof tiles. The modules were fitted into the tile battens using nails shot from the nail gun.

Table 5. Physical specification for each ceiling model (in a modular dimension of $50 \times 50 \mathrm{~cm}$ )

\begin{tabular}{|c|c|c|c|c|c|c|c|c|}
\hline \multirow[b]{2}{*}{$\begin{array}{l}\text { Module } \\
\text { type }\end{array}$} & \multirow[b]{2}{*}{$\begin{array}{l}\text { No. of } \\
\text { layer }\end{array}$} & \multicolumn{4}{|c|}{ No. of pcs of bamboo slats } & \multirow{2}{*}{$\begin{array}{l}\text { Distance } \\
\text { between } \\
\text { pcs. (cm) }\end{array}$} & \multicolumn{2}{|c|}{ Modular thickness } \\
\hline & & $\begin{array}{l}\text { Layer } 1 \\
\text { (lower) }\end{array}$ & $\begin{array}{l}\text { Layer } 2 \\
\text { (upper) }\end{array}$ & $\begin{array}{c}\text { per } \\
\text { module }\end{array}$ & Ratio & & $\begin{array}{l}\text { Thickness } \\
\text { (cm) }\end{array}$ & Ratio \\
\hline $\begin{array}{c}\text { Single } \\
\text { (type 1) }\end{array}$ & 1 & 13 & 0 & 13 & 1 & 0 & 1.4 & 1 \\
\hline $\begin{array}{l}\text { Double } \\
\text { (type 2) }\end{array}$ & 2 & 13 & 12 & 25 & 1.92 & 0 & 2.77 & 1.97 \\
\hline $\begin{array}{l}\text { Hollow } \\
\text { (type 3) }\end{array}$ & 2 & 9 & 8 & 17 & 1.31 & 2 & 2.62 & 1.87 \\
\hline
\end{tabular}

(Source: Author's analysis, 2019) 


\subsection{Method of data collection}

All three types of the modular bamboo ceiling were installed and tested in a real condition in the same room inside a conventional house setting in Yogyakarta, as presented in Figure 8. To investigate the effectiveness of the three construction models on overcoming problems associated with the second type of slanted ceiling (the one fitted between the common rafter and the tile battens), two kinds of measurements were taken on the surface of the material. The first measurement was the surface temperature, and the second one was surface humidity. Each of the measurements was taken periodically once every hour for 24 consecutive hours on February 10, 2019. The measurement of the surface temperature was taken using Environment Meter-9000, and the measurement of the humidity was taken using Wood Moisture Tester Model GM605. The tools used in this research are illustrated in Figure 9. For each model, there were 10 measurement points for simultaneous measurements of both material properties during each measurement period. As each model was made up of two modules, those measurement points were distributed evenly in those modules within the same height or level -except for the third module where some of the points were located in the upper layer, and the rest were located on the lower one. The distance between each measurement point was set for around 8-12 $\mathrm{cm}$, as shown in Figure 10.

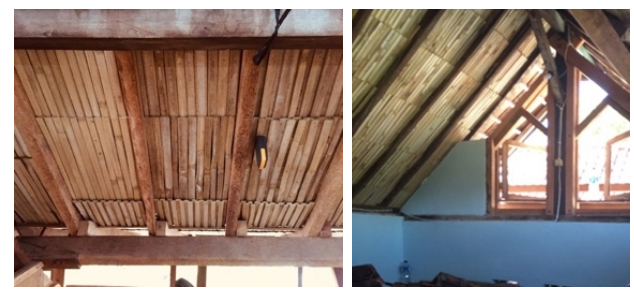

Figure 8. Tested models installed in a room (Image source: Author, 2018)

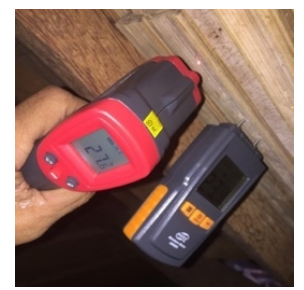

Figure 9. Measurement tools used in this research (Image source: Author, 2018)
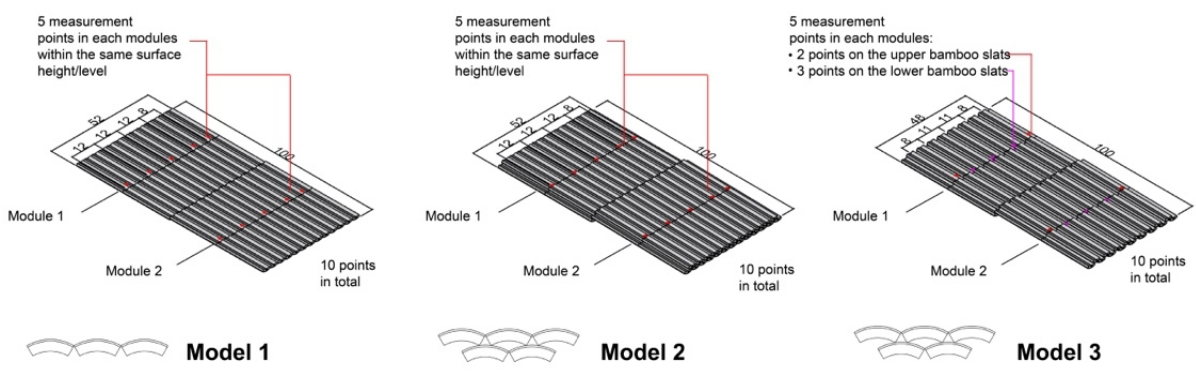

Figure 10. Measurement points for the three models (Image source: Author, 2019)

\section{Result and discussion}

\subsection{Construction process}

\section{Customized modularity}

The use of modular construction in the research prototype was specifically designed to overcome problems related to the limited access to maintenance. Modularity allowed partial replacements by the user only on the affected areas of the ceiling. As in for the dimension of the module built for the research, it was customized according to the actual distance between each common rafter of the roof. This flexibility was very crucial to accommodate various module dimensions needed during ceiling installation on places 
with variations in terms of distances between elements in the roof structure. In particular, this circumstance could be very highly related to many traditional houses that were built without the specific skill of master builders; thus, it might have an asymmetric arrangement and irregular distance between each common rafter. Practically, any gaps that might occur after the installation of modules with a certain dimension could be closed by adding one or two more pieces into the end of the ceiling area.

Furthermore, the free dimensioning of the module was also intended to eliminate problems caused by limited access to maintenance by allowing a direct overlapping of new ceiling modules on top of the previously worn out sections of the old ceiling material. This customization was done according to the design logic behind the construction technique; which was to construct an effective, efficient and fully performing bamboo ceiling. The crucial aspects of such bamboo ceiling are including easy-installation, easy-maintenance, durable and an indication of positive contribution towards the room's thermal performance. As in for the length of the bamboo slats, twice the dimension of tiles equals to a larger coverage; which ultimately requires less construction time. Moreover, the additional $10 \mathrm{~cm}$ was also designed to create overlapping rows of modules in a continuous pattern to ensure that the ceiling was secured enough to protect the enclosed space from dirt flakes while still allowing adequate air circulation through its sequential raised levels, as illustrated in Figure 11.

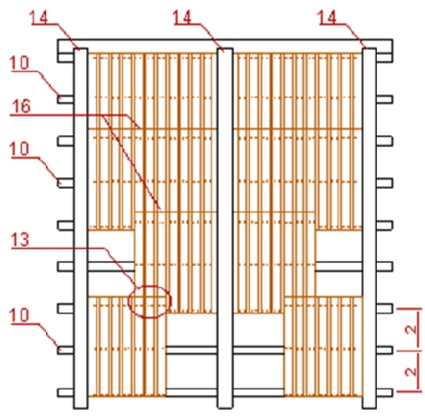

Figure 11. Overlapping pattern of modular ceiling (Image source: Pradipto, 2019)

\section{Skin orientation}

In all models, the modules were placed in a way that the outer skin of the bamboo slat was facing the tile battens, and the inner part of the bamboo slat was facing the enclosed space. By applying this method of construction, there were a number of advantages that followed, including the one related to material efficiency and another one related to maintenance efficiency. In relation to material efficiency, this method allowed the utilization of a large range of bamboo conditions.

Bamboo is a natural product, therefore is very common to have color variations. Although color variation does not affect bamboo's structural performance as a building material, when it is used as interior elements such as ceiling, color has become a more important feature as it reflects light that will influence the overall lighting of the space. Therefore, facing the inner skin of the bamboo to the enclosed space will eliminate concerns regarding the physical look of the material as the inner skin of any bamboo has nearly identical light color and texture. Thus, any kind of bamboo could be utilized regardless of their external physical condition. To some extent, this strategy even allowed the usage of bamboos with a minor physical defect on the outer skin. Furthermore, the inner side of the bamboo, often referred to the flesh, is the one that is highly prone to fungus and insect attack. Therefore, placing it towards the enclosed room is an effective way to increase the durability of the material by the ease of maintenance. 
On the other hand, the outer skin of the bamboo is coated by a layer of natural wax that is highly resistant to water. This wax prevents water to penetrate the inner section of the bamboo. Consequently, the ceiling with such material durability on the side facing the tiles gives the advantages of an additional layer of protection towards rain seepage.

\subsection{Measurement results}

The result of the temperature measurement on the surface of the material for the three types of modules in comparison to the room temperature is presented in Table 6, while the graph illustrating the temperature differences between them is presented in Figure 12.

Table 6. Result of material temperature measurement

\begin{tabular}{cccccc}
\hline & $\begin{array}{c}\text { Measurem } \\
\text { ent time } \\
\text { (hour) }\end{array}$ & $\begin{array}{c}\text { Room } \\
\text { temperat } \\
\text { ure ('C) }\end{array}$ & \multicolumn{3}{c}{$\begin{array}{c}\text { Material's surface } \\
\text { temperature ('C) }\end{array}$} \\
\hline 1 & 0 & 27.8 & 24.5 & 24.8 & 25 \\
2 & 1 & 27.6 & 26.6 & 24.7 & 27 \\
3 & 2 & 27.5 & 26.5 & 26.7 & 26.2 \\
4 & 3 & 27.3 & 26.4 & 25.8 & 26.2 \\
5 & 4 & 27 & 26.2 & 26.5 & 26.3 \\
6 & 5 & 26.2 & 25.7 & 25.4 & 25.7 \\
7 & 6 & 26.5 & 22.5 & 23.7 & 22.4 \\
8 & 7 & 27 & 26.4 & 26.2 & 26.5 \\
9 & 8 & 27.7 & 26.4 & 26.5 & 26.1 \\
10 & 9 & 27.4 & 29.1 & 28.3 & 26.3 \\
11 & 10 & 28.2 & 29.3 & 29.6 & 29.3 \\
12 & 11 & 29.8 & 30.4 & 29.7 & 30.2 \\
& & & & & \\
\hline
\end{tabular}

\begin{tabular}{|c|c|c|c|c|c|}
\hline \multirow{2}{*}{ z } & \multirow{2}{*}{$\begin{array}{c}\text { Measurem } \\
\text { ent time } \\
\text { (hour) }\end{array}$} & \multirow{2}{*}{$\begin{array}{c}\text { Room } \\
\text { temperat } \\
\text { ure ('C) }\end{array}$} & \multicolumn{3}{|c|}{$\begin{array}{c}\text { Material's surface } \\
\text { temperature ('C) }\end{array}$} \\
\hline & & & Single & Double & Hollow \\
\hline 13 & 12 & 30.4 & 35.9 & 35.5 & 33.4 \\
\hline 14 & 13 & 31.9 & 32.6 & 35 & 31.8 \\
\hline 15 & 14 & 31.4 & 32.6 & 31.8 & 32.1 \\
\hline 16 & 15 & 30.9 & 31 & 31 & 30.7 \\
\hline 17 & 16 & 28.4 & 32.7 & 31.9 & 32.8 \\
\hline 18 & 17 & 28.8 & 29 & 29.3 & 29.1 \\
\hline 19 & 18 & 23.9 & 28.2 & 27.9 & 28.2 \\
\hline 20 & 19 & 25.6 & 27.1 & 27.4 & 27.2 \\
\hline 21 & 20 & 26.9 & 27.7 & 26.3 & 27.4 \\
\hline 22 & 21 & 27 & 26.9 & 27.2 & 26.8 \\
\hline 23 & 22 & 27.7 & 26.9 & 26.4 & 27.1 \\
\hline 24 & 23 & 29.6 & 25.1 & 25.2 & 24.8 \\
\hline \multicolumn{2}{|c|}{ Mean value } & 28.02 & 28.15 & 28.03 & 27.86 \\
\hline
\end{tabular}

(Source: Author's analysis, 2019)

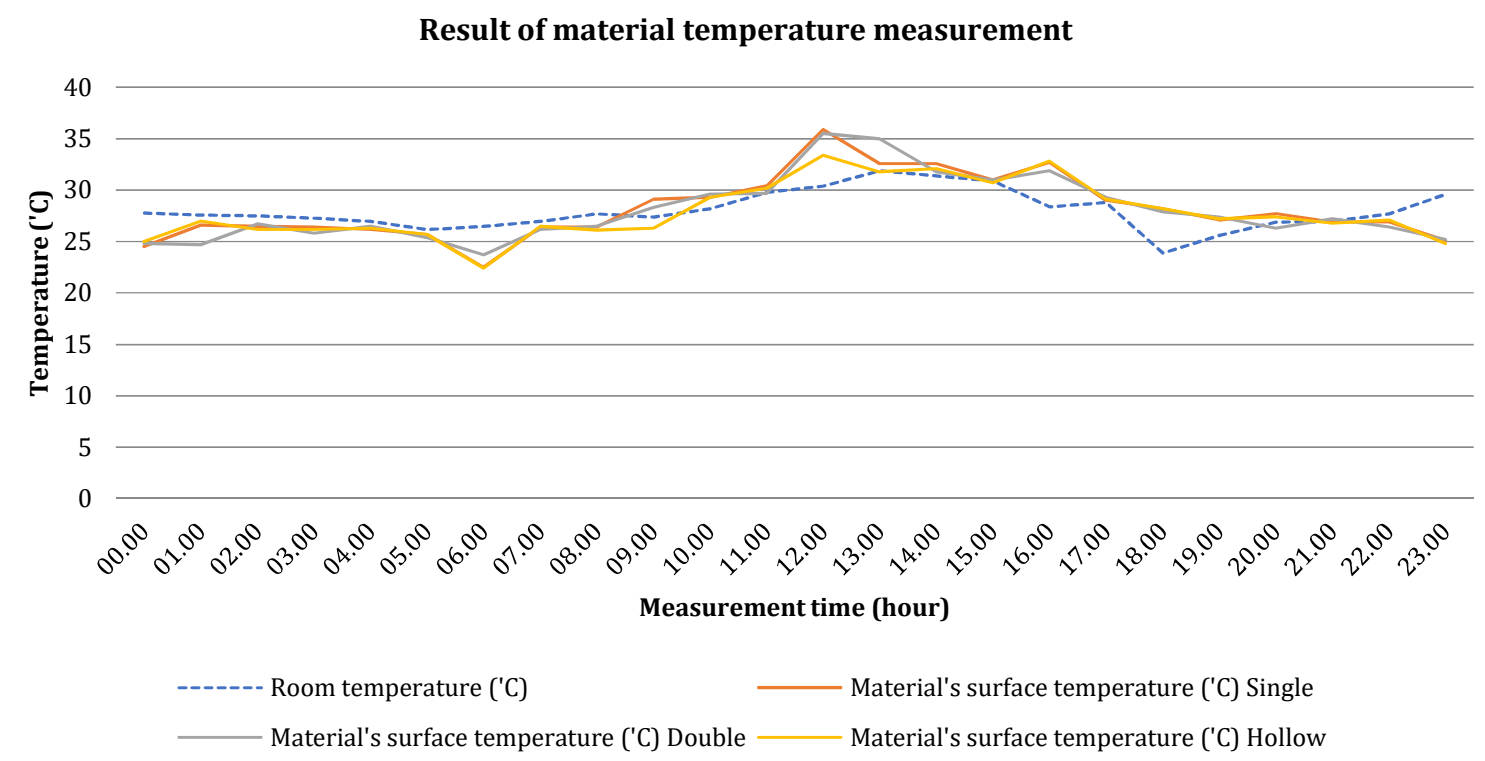

Figure 12. Graph illustrating differences between each temperature measurement

(Source: Author's analysis, 2019)

In the graph above, the temperature changes in term of room temperature are drawn in a dashed line to distinguish it from the other three comparable surface material temperature data. Based on the result, there was a mismatch linear relationship between the surface temperature and the amount of material layer and a match linear relationship between the surface temperature the density of the material. A larger number of layering provided larger thermal mass and low density of material resulted in better air circulation. 
In short, a bigger number of layers and lesser dense material led to lower material temperature. Therefore, the third type of ceiling which is the hollow ceiling had the lowest average temperature measurement on its surface material.

Next, the result of the humidity measurement on the surface of the material for the three types of modules is presented in Table 7, while the graph illustrating the humidity differences between them is presented in Figure 13.

Table 7. Result of material humidity measurement

\begin{tabular}{|c|c|c|c|c|}
\hline \multirow{2}{*}{ No } & \multirow{2}{*}{$\begin{array}{c}\text { Measurement } \\
\text { time (hour) }\end{array}$} & \multicolumn{3}{|c|}{ Material's surface humidity (\%) } \\
\hline & & Single & Double & Hollow \\
\hline 1 & 0 & 22.2 & 20.3 & 21.5 \\
\hline 2 & 1 & 24.2 & 21.4 & 23.5 \\
\hline 3 & 2 & 24.3 & 22 & 23.5 \\
\hline 4 & 3 & 24.9 & 22.1 & 24 \\
\hline 5 & 4 & 24.2 & 23.6 & 24.1 \\
\hline 6 & 5 & 23 & 24.7 & 25.2 \\
\hline 7 & 6 & 25.5 & 22.7 & 22.8 \\
\hline 8 & 7 & 27.4 & 25.3 & 26.3 \\
\hline 9 & 8 & 28.6 & 24.5 & 25.8 \\
\hline 10 & 9 & 27 & 24.2 & 28.2 \\
\hline 11 & 10 & 27.3 & 24.6 & 25.8 \\
\hline 12 & 11 & 26.3 & 24.3 & 25.2 \\
\hline
\end{tabular}

\begin{tabular}{ccccc} 
No & $\begin{array}{c}\text { Measurement } \\
\text { time (hour) }\end{array}$ & \multicolumn{3}{c}{ Material's surface humidity (\%) } \\
& & Single & Double & Hollow \\
\hline 13 & 12 & 21.1 & 19.7 & 20.8 \\
14 & 13 & 17.7 & 18.2 & 17.3 \\
15 & 14 & 19.4 & 18.3 & 19.2 \\
16 & 15 & 20.5 & 18.8 & 20.4 \\
17 & 16 & 23.3 & 21.8 & 23.5 \\
18 & 17 & 20.8 & 18.9 & 20.5 \\
19 & 18 & 22.9 & 19.6 & 21.7 \\
20 & 19 & 22.7 & 20.3 & 21.8 \\
21 & 20 & 23.9 & 20.8 & 21.1 \\
22 & 21 & 23.4 & 21.3 & 22.7 \\
23 & 22 & 23.6 & 22 & 22.5 \\
24 & 23 & 21.7 & 20.1 & 21.8 \\
& Mean value & $\mathbf{2 3 . 5 8}$ & $\mathbf{2 1 . 6 5}$ & $\mathbf{2 2 . 8 7}$ \\
\hline & \multicolumn{3}{c}{} \\
\hline
\end{tabular}

(Source: Author's analysis, 2019)

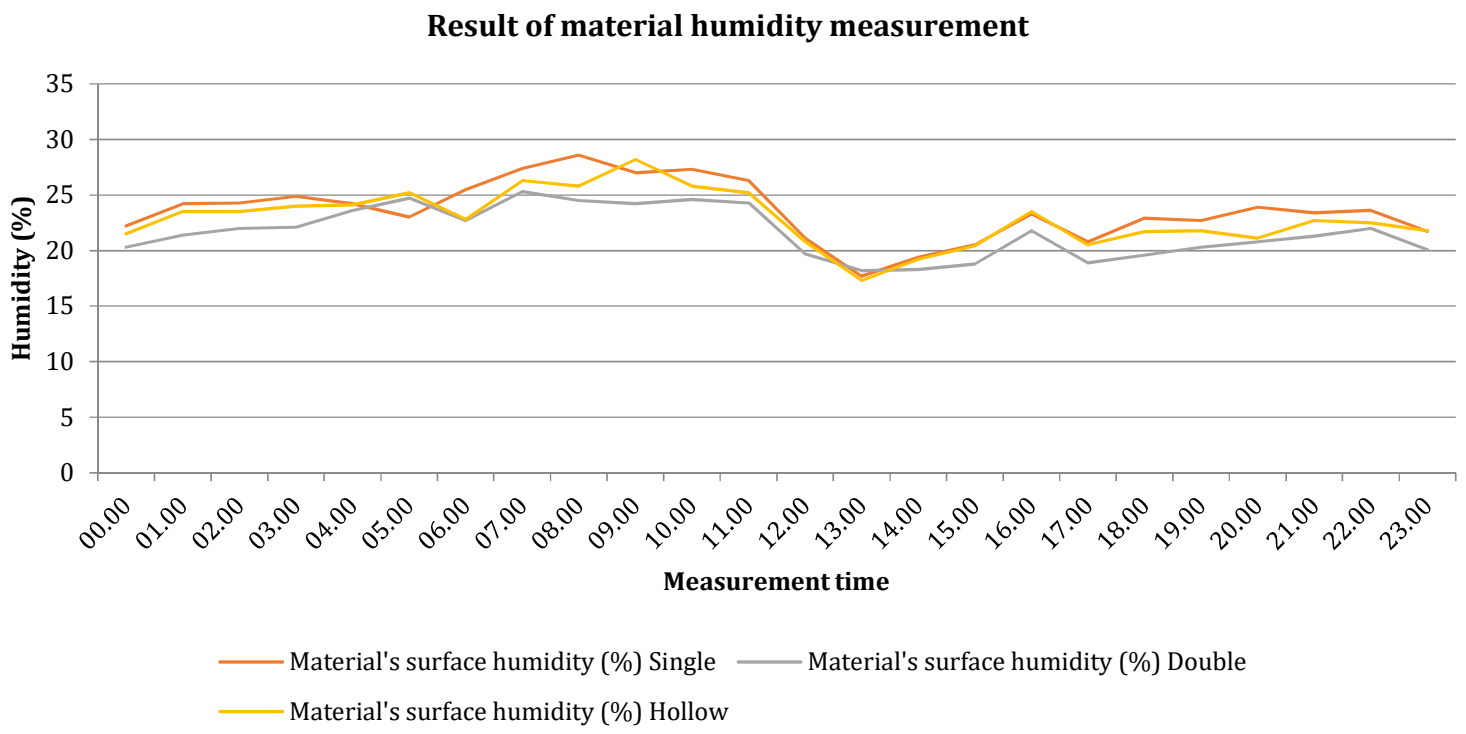

Figure 13. Graph illustrating differences between each humidity measurement (Source: Author's analysis, 2019)

Then, there was a matching linear relationship between the material humidity and both of the amounts of the material layer and the density of the material. Larger amount of material layering and dense arrangement of material provided larger and tighter boundaries between the outer surfaces of the ceiling (which had a direct contact with the enclosed space) the inner surface of the ceiling (which had a direct contact with the space underneath the tiles that was more prone to water seepage through the gaps between the tiles). The aforementioned better air circulation found in the third type of the ceiling model (the hollow type) carried water within the air; thus, it contributed to a higher material humidity. Then, thinner ceiling material in the first type of ceiling model (the single type) 
was easier to penetrate by water through its material capillarity; thus, it also contributed to higher material humidity. Hence, the second type of ceiling, the double ceiling, has the lowest average humidity measurement when reviewed from its surface material humidity.

\section{Conclusion}

\subsection{Relationship between the method of construction, material's surface temperature and material's surface humidity}

From the results above, it could be seen that the third type of ceiling, the hollow type, had the lowest temperature measurement. Although the average differences were insignificant, $0.30^{\circ} \mathrm{C}$ with the first type of ceiling and $0.17^{\circ} \mathrm{C}$ with the second type of ceiling, the data show more striking comparison with more than $5^{\circ} \mathrm{C}$ different for all the two models after being reviewed selectively during the hottest hours of the day from 9 AM to $3 \mathrm{PM}$. These temperature differences were caused by the continuous air circulation made possible by the patterned gap in between the bamboo slats. Although the measurement was done upon the surface's temperature, this was an indication that this type of ceiling provided the best thermal performance for the enclosed room.

Then, as for the humidity measurement, the data show that the second type of ceiling which was the double-layered type had the lowest humidity measurement with $1.93 \%$ difference with the first type of ceiling (the single-layered type) and $1.22 \%$ difference with the third type of ceiling (the hollow type). As previously mentioned, although the second type of ceiling was recorded as the ceiling with the lowest temperature, it was not recorded as the ceiling with the lowest humidity measurement. This situation was due to the continuous air circulation found in this type of ceiling. This air circulation carried water within the gaps of the material that caused not only a lower temperature but also an increase in the humidity on the material surface.

\subsection{Overall potential benefit}

In this paper, the temperature and humidity measurement were conducted only to compare related data between three types of ceiling construction designed with the idea of developing a modular ceiling made of a simple arrangement of similar (although not necessarily identical) natural elements of bamboo slats. However, in the bigger context, the whole construction principles of these ceilings should be seen as an alternative architectural engineering solution to overcome practical problems commonly associated with various types of ceiling, including the ones made of natural materials and non-natural materials, as presented in the following Table 8.

Table 8. Constructional design implication towards various types of ceiling

\begin{tabular}{|c|c|c|c|}
\hline Ceiling condition & $\begin{array}{c}\text { Commonly associated } \\
\text { problems }\end{array}$ & Construction method & Improvement implication \\
\hline \multirow{2}{*}{$\begin{array}{l}\text { Slanted ceiling fitted } \\
\text { in between the } \\
\text { common rafter and } \\
\text { the tile battens }\end{array}$} & $\begin{array}{l}\text { Relatively small air } \\
\text { insulation }(2-3 \mathrm{~cm}) \text { leads } \\
\text { to rapid outdoor heat } \\
\text { transfer }\end{array}$ & $\begin{array}{l}\text { Doubled layer bamboo } \\
\text { slats }\end{array}$ & $\begin{array}{l}\text { The pocket of air space (in a sequential pattern) } \\
\text { which is large enough to perform as air insulation } \\
\text { but is too limiting for pest's inhabitant }\end{array}$ \\
\hline & $\begin{array}{l}\text { Limited access for } \\
\text { maintenance }\end{array}$ & Modular construction & $\begin{array}{l}\text { Ease of construction as a damaged module could } \\
\text { be uninstalled for a partial replacement that is } \\
\text { applied only on that particular module }\end{array}$ \\
\hline \multirow[b]{2}{*}{$\begin{array}{l}\text { Ceiling made of an } \\
\text { intact single sheet of } \\
\text { material }\end{array}$} & $\begin{array}{l}\text { Limited access for } \\
\text { maintenance }\end{array}$ & Modular construction & $\begin{array}{l}\text { Ease of construction as a damaged module could } \\
\text { be uninstalled for a partial replacement that is } \\
\text { applied only on that particular module }\end{array}$ \\
\hline & $\begin{array}{l}\text { High room temperature } \\
\text { (apart from factors such as the } \\
\text { height of the room, cross-air } \\
\text { circulation, air conditioner, } \\
\text { electronic fan, and others) }\end{array}$ & $\begin{array}{l}\text { Two overlapping } \\
\text { layers of sparsely } \\
\text { weaved bamboo slats }\end{array}$ & $\begin{array}{l}\text { Continuous air circulation through the patterned } \\
\text { gaps between the bamboo slats }\end{array}$ \\
\hline
\end{tabular}




\begin{tabular}{llll}
\hline $\begin{array}{l}\text { Modular construction } \\
\text { on an asymmetrical } \\
\text { roof }\end{array}$ & $\begin{array}{l}\text { Different dimensions } \\
\text { between elements in the } \\
\text { roof structure }\end{array}$ & $\begin{array}{l}\text { Customized modular } \\
\text { made of similar } \\
\text { individual elements }\end{array}$ & $\begin{array}{l}\text { In-place adjustment on the modular dimension by } \\
\text { adding a certain number of additional elements } \\
\text { as needed }\end{array}$ \\
\hline Source: Author's analysis, 2019) &
\end{tabular}

Furthermore, it is also important to note that the construction method that regulates the orientation of the material also exhibited some very important principles of material durability and efficiency. By facing the inner skin of the bamboo into the interior room, the risk associated with fungi and insects could be highly minimized as a result of the available clear visual of the highly damaged-prone part of bamboo. Moreover, it also allows a higher material efficiency by allowing the use of bamboo with low visual quality due to the minimized visual access to the outer skin of the bamboo.

\section{Acknowledgment}

This research was supported by the Ministry of Research, Technology and Higher Education in Indonesia through 'Penelitian Unggulan Perguruan Tinggi' program in 2017. The authors thank Natasha Nurul Annisa for her assistance in the early process of manuscript writing.

\section{Reference}

Adiyanto, J. (2012). Ruang Bersama di Kolong Studio Akanoma (Ke-kini-an Arsitektur Jawa). "Ruang Bersama Nusantara" Untuk Kehidupan Yang Lebih Baik, B1-B9. Retrieved from http://eprints.unsri.ac.id/3672/1/SAN_1_UB_12_Des_12.pdf

Ambarwati, D. R. S. (2009). Kontinuitas dan Perubahan Vastusastra pada Bangunan Joglo Yogyakarta. Surya Seni: Jurnal Penciptaan Dan Pengkajian Seni, 5(2), 123-133.

Australia Plus ABC. (2016). Filosofi "Manunggaling Kawulo Gusti" Dibedah di Sydney. Retrieved August 25, 2019, from detiknews website: https://news.detik.com/abcaustralia/d-3291965/filosofi-manunggaling-kawulo-gusti-dibedah-di-sydney

Casas na Terra. (2017). Design and Architecture. Retrieved August 25, 2019, from Casas na Terra website: http://www.casasnaterra.com/en/houses/design-and-architecture/

Mangunwijaya, Y. B. (2009). Wastu citra: pengantar ke ilmu budaya bentuk arsitektur sendisendi filsafatnya beserta contoh-contoh praktis (4th ed.). Retrieved from https://books.google.co.id/books?id=nZgew4Ad-

$7 \mathrm{gC} \& \mathrm{pg}=\mathrm{PP} 6 \& \mathrm{hl}=\mathrm{id} \&$ source=gbs_selected_pages\&cad=3\#v=onepage\&q=makro\&f=f alse

Pradipto, E. (2019). Konstruksi Plafon Miring Antar Usuk. Indonesia: Direktorat Jenderal Kekayaan Intelektual Kementerian Hukum Dan Hak Asasi Manusia Republik Indonesia (under patent registration; registraton date: September 19, 2017; registration number: P00201706281).

Raj, D., \& Agarwal, B. (2014). Bamboo as a building material and its processing methods. Journal of Civil Engineering and Environmental Technology, 1(3), 56-61.

rumahjoglo.net. (2015). Rumah adat jawa model limasan. Retrieved August 25, 2019, from https://rumahjoglo.net/component/tags/tag/6-rumah-adat-jawa-modellimasan.html

Steeman, M., Janssens, A., Steeman, H. J., Van Belleghem, M., \& De Paepe, M. (2010). On coupling $1 D$ non-isothermal heat and mass transfer in porous materials with a multizone building energy simulation model. Building and Environment, 45(4), 865877. https://doi.org/10.1016/j.buildenv.2009.09.006

Triyuwono, I. (2011). Mengangkat "Sing Liyan" untuk Formulasi Nilai Tambah Syari'ah. Jurnal Akuntansi Multiparadigma, 2(2), 186-200. 
Umar, M. Z., Faslih, A., \& Rosyidah, S. (2018). Jiwa Puitis Nenek Moyang Orang Buton dalam Mendirikan Rumah Tradisional Buton Malige di Kota Baubau. Jurnal RUAS, 16(1), 1323.

Wimmer, R. (2013). Adapting Zero Carbon Houses for Tropical Climates - Passive Cooling Design in the Philippines. SB13 Sustainable Buildings, Infrastructure and Communities in Emerging Economies. Retrieved from https://www.irbnet.de/daten/iconda/CIB_DC26748.pdf 